Conservación de mamíferos:

fronteras científicas y trampas socio-políticas

\title{
Mammalian conservation: scientific frontiers and socio-political pitfalls
}

William Z. Lidicker, Jr. ${ }^{1^{*}}$

\footnotetext{
${ }^{1 *}$ Museum of Vertebrate Zoology, University of California, Berkeley, USA 94720-3160 e-mail address: wlidicker@berkeley.edu ${ }^{*}$ Corresponding author
}

\begin{abstract}
Introduction: The frontiers of conservation biology are rapidly advancing. This is partly because of scientific achievements, but also it is because the human predicament continues to deteriorate in spite of heroic but inadequate efforts to make the human enterprise sustainable. Of greatest importance is the need to escape from the confrontational mode that pervades our social and political discussions. We must trade this conflict for a realization that there is only one objective for all of humanity, and that is the sustainability of human civilization. Mammalian conservation can play a major role in this struggle, but to do this we must take the initiative to promote meaningful dialogue with politicians, policy makers, economists, sociologists, and the public at large. At the same time, we must continue to be at the frontiers of our science while not neglecting the pursuit of much needed basic research on taxonomy, life history, and distribution of the world's mammals.
\end{abstract}

Some social, political, and strategic considerations: Themes suggested to enhance such communication are: non-confrontational cooperation, life support services, optimism, systems thinking, and adapting to various political regimes.

Frontiers of conservation science: Eight leading edge topics are suggested for the science component of conservation: 1) community tipping points, 2) trophic cascades, 3) landscape or ecoscape perspective, 4) role of common species in community dynamics, 5) climate change complications, 6) role of genetics, 6) social dynamics, 7) microorganism synergisms, and 8) translocations. Mammalian conservationists are poised to play a significant role in humanity's efforts to confront the myriad of intertwined problems that we face. Given that humans belong to the same taxonomic class that is the subject of our expertise, we have special responsibility to provide that leadership.

Key words: captive breeding, climate change, community tipping points, conservation genetics, cooperation, landscape perspective, life support services, microbiota synergisms, new conservation, optimism, social behavior, sustainable civilization, systems perspective, translocations, trophic cascades.

\section{Introduction}

The conservation of mammals on the world stage promises to be a major player as we struggle forward to save civilization from the ravages of population growth, accelerating per capita consumption, climate change, and inevitable social, economic, and political turmoil. In doing this, it will have to maintain a position of being at the frontiers of conservation science while at the same time being in a strong position to engage in necessary collaboration with social scientists, policy makers, economists, and political leaders. Such a synergism is essential if we are to succeed in this endeavor. Mammalogists have a special advantage in this undertaking in that the human species falls within the taxon (Class Mammalia) of their special expertise. 
In this essay I will outline my thoughts on some major areas of conservation research that I feel will be at the leading edge of our efforts to improve our understanding of mammalian conservation, enhance our management tools for conservation, and facilitate cooperation with other disciplines and even with the public. I will also call attention to predictable difficulties on the political, policy, economic, and management side. While pursuing these major objectives, we need to remain cognizant that much remains to be discovered about the more than 5500 species of mammals with which we share the Earth. New species are being discovered every year, and for only a very small percentage of the known species do we have sufficient knowledge of their life histories, genetic structure, and adaptive potential to develop conservation strategies for them. Thus, the ongoing exploration of what species exist, what are their distributions, what are the details of their life histories, and what are their evolutionary histories and likely future adaptabilities, all must continue vigorously.

\section{Some Social, Political, and Strategic Considerations}

To be effective, conservation planning must be implemented, monitored, and continually revised. This means that while good conservation science is necessary, it is not sufficient. It is therefore imperative that we develop communication links with non-scientists who will be critically needed for implementation (Sörlin 2012). This cadre of potential collaborators includes politicians, policy makers, various types of social scientist, and, most importantly, the local citizenry where the conservation project is to be located. Communication must also be maintained with citizen environmentalists and NGO's that support conservation causes. This last group constitutes important allies in the cause of conservation, but for the most part they represent a different audience than do the politicians, etc. who are usually not, at least initially, mentally or emotionally involved in conservation. Our goals need to be: a) making sure that the importance of conservation to all of humanity is continually emphasized; b) passing on the results of the best scientific knowledge available to the environmentalist community so that they can be increasingly effective in their efforts; and c) developing communication bridges with the politician, etc. communities so that they are willing to listen to us, and then hopefully cooperate in implementation. A particularly intractable communication problem is found where ideological beliefs close off even the possibility of rational discussion on conservation issues (Feinberg and Willer 2011). Here are some suggested guidelines for pursuing these goals.

Non-environmentalists often view the conservation community as a special interest group, and therefore ignorable. We are considered to be obstructionists, fuzzy-minded idealists, anti-economic growth proponents, job destroyers, nature lovers, tree huggers, and generally opposed to progressive and healthy business activities. In fact, our special interest group is human civilization which we would like to see continue into the future in a sustainable way. Because this view is fortunately widely shared, even if not often articulated, it is important not to use language that implies that there are two antagonistic groups: conservationists and everyone else. For example, when conservationists say that they "want to save Nature" because they like it, it has intrinsic value, or because they want to save species from extinction, it drives a wedge between them and the rest of humanity who don't care about such things. An example of well-meaning language that needs to be avoided in the future, published recently (2014) by a supporter of the World Wildlife Fund in their newsletter, reads "I appreciate the WWF's global mission to balance the needs of nature and people." There is in fact no balance, but only a single common goal. This basic conceptual dichotomy is improved somewhat by the so-called "new conservation" (Marvier 2014) which involves advocating that human needs be incorporated explicitly into 
conservation so that conservation becomes more palatable to non-environmentalists, and therefore more successful. While this new emphasis does not diminish the importance of the traditional conservation approaches, it fails to fundamentally change the "us vs them" philosophy. It only says "let's talk" and by cooperation we will accomplish more. At this point in human history, we need a new paradigm, namely that there is only "us"; our common goal of sustainable human civilization requires both conservation of biodiversity and the support and participation of everyone else on the planet.

A powerful argument for conservation is the preservation of "ecosystem services" for the benefit of mankind. Our agriculture, weather, renewable resources, drug industry, flood control, disease control, invasive species control, etc. depend on such services. However, it is fair to surmise that a large majority of non-ecologists have minimal understanding of the word "ecosystem" even though it is increasingly being used in public discourse. I think we should instead use less esoteric expressions like "human services," "life support services," and "natural community services."

Given the deteriorating conditions on Earth, it is increasingly difficult to remain optimistic about humanity's resolve to effectively deal with our predicament. However, we must express optimism that improvements are actually possible without major catastrophes providing an incentive for action, and we must do this without losing a firm grasp of reality (Swaisgood and Sheppard 2010, Lidicker 2011, Redford et al. 2011). We must be ready to explain what things inspire hope for humanity, and conversely what things prompt despair. Pessimism alone leads to inaction and cynicism. Optimism on the other hand, can more readily recruit new adherents to conservation causes, as well as encourage positive actions, and thus encourage positive feedback loops. Conservation researchers should routinely make it clear what tangible benefits for humanity they anticipate from their projects and/or how the research might alleviate negative influences on our life support system (Lidicker 2011).

Although not appropriate for all audiences, where possible we should explain to non-scientists the essence of systems thinking. Life on Earth can be viewed as organized into living systems of varying complexity, such as cells, organisms, populations, and communities. Systems at one level of complexity can be grouped into larger more complex systems (for example, cells assembled to form an organism). Systems at all levels have a boundary and are composed of parts that interact with each other to produce new (emergent) properties. Reference to familiar non-living systems such as a car or computer can be constructive. Imagine a pile of all the disconnected parts that make up a car or computer and compare that to those parts assembled into a functioning system. The potential impacts of missing parts, such as resulting from extinctions or dispersal barriers, can thus be more easily conceptualized. In general, understanding the systems concept should make it easier to comprehend how successful conservation projects work as well as to appreciate why human interests and conservation are inseparable in the pursuit of survival for human civilization.

Conservation projects and regulations occur in the context of political systems that vary greatly across the Earth and over time. Successful implementation of conservation actions requires that this context be understood along with the associated cultural variations. Conservation actions can be accomplished in almost any political system, but are perhaps least likely to be successful where public participation and scientific input are impeded such as in authoritarian governments and corporate oligarchies.

\section{Frontiers of Conservation Science}

Consistent with its role as a major participant in conservation, mammal conservation takes its place at the leading edge of the research enterprise. To illustrate this, I have attempted to assemble a list of research areas that I believe are at the frontier of conservation science with an emphasis on 
mammals. The order of presentation carries no implication of priorities. At the outset, however, I would like to mention again the importance of three non-frontier areas that require ongoing attention. The first is the continuing search for undescribed species and for new distribution records. New species are being regularly discovered, and it is obviously critical to know details of the distribution of each species. Shifts in distribution range, and persistent declines in numbers are also essential information. The second area is that of life history knowledge. Only a very small fraction of known species have their life history parameters well documented. For widespread species, geographic uniformity in these features cannot be assumed, and information needs to be documented from across the species distribution. The third non-frontier area is that of population genetic structure and evolutionary potential. Although these are traditional research areas, there are many new techniques available that make it now much easier to follow movements such as dispersal or migratory pathways, to observe behavior of individuals, to determine social networks, to measure physiological and disease states, to determine food habits, vocalizations, genotypes, etc.

Community tipping points. Usually, when an ecological community is perturbed by a disturbance and the disturbance is subsequently removed, the community will return to something resembling its original state. Ecologists and conservationists depend on such resilience to restore damaged communities. It is now clear, however, that many if not most communities have an unstable equilibrium level of disturbance (sometimes called a tipping point) such that disturbances more severe than those typically experienced do not allow recovery even when the disturbance is removed. Instead, a new type of stable community is formed. As restoration of communities becomes more and more common in conservation, we need to learn more about the nature of these tipping points. Can we someday predict if and when they will occur? Dai et al. (2012) and Fung et al. (2013) suggest possible methods for this. Sometimes there may be the loss of a keystone or dominant species from the community that forces major reorganization. Perhaps there may be a role for species diversity to be an important factor influencing the nature of this potential disequilibrium. Groups of mutualists (cooperons; Levchenko and Kotolupov 2010) are another possible agent of such disequilibrium. The phenomenon seems analogous to the Allee effect (anti-regulation) in population dynamics (Lidicker 2010). It is now widely accepted that positive species interactions (coactions) are as important in structuring ecological communities as are negative interactions (Boucher 1985, Dugatkin 1997, White and Torres 2009, and Kozo-Polansky et al. 2010), and this fact provides clues in the search for and prediction of possible drivers of community tipping points.

Trophic cascades. Aside from the important community adjustments that occur when a top predator is lost from a community, there is much current interest in conservation of the top carnivores themselves (Estes et al. 2011, Ripple et al. 2014a, 2014b). Since they occur in relatively small numbers and generally require very large home ranges, they are often highly sensitive to habitat loss and degradation. Moreover, nature reserves are generally too small to support populations of top carnivores that are large enough to be sustainable. Also, to avoid genetic inbreeding or stochastic reductions in numbers to non-viable levels, it is often imperative to connect multiple small reserves with appropriate corridors for these carnivores to use at least occasionally. The required features of such corridors then need to be determined. Further complications arise if these top predators are killed for trophies or to protect livestock (Chapron and López-Bao 2014). Two newly discovered reasons for conserving top predators are their possible role in the storage and flux of atmospheric carbon (Wilmers et al. (2012), and in countering the negative effects of anthropogenic nutrient loading. Hughes et al. (2013) provide an example of this unanticipated benefit of top predators involving a 4-level trophic cascade. 
Landscape perspective. As ecologists have learned to think in systems contexts, they have tackled analyses of larger and larger chunks of real estate, and even explicitly included man-modified habitats. This revolution in thinking occurred in the mid-1980s (Lidicker 1995, 2007, Wiens et al. 2007), and has rejuvenated the concept of landscape ecology. This term, however, is currently applied to any study area that is large in size from a human perspective. Because of this, the designation of landscape has become disconnected from the traditional hierarchy of systems familiar to ecologists. Steps in hierarchical systems are based on major changes in system complexity, not on size, and they are characterized by new emergent properties. Cell systems are organized into organism systems, which in turn are grouped into population systems (more than one individual organism of the same kind or species). Populations of different kinds of organisms are organized into community systems. The next logical higher level would be systems composed of more than one kind of community. Although landscapes would often contain more than one community-type, this feature is not built into the landscape definition. To fill this need, I have suggested the term "ecoscape" for this (Lidicker 2008). Ecoscapes have novel emergent properties such as edge effects (Lidicker 1999, Lidicker and Peterson 1999), community fragmentation properties, meta-population dynamics, connectedness, inter-patch fluxes of energy, nutrients, organisms, and information, temporal stability, and resilience. Research in mammalian conservation will contribute to and profit from ecoscape level approaches.

Role of Common Species. There is a natural tendency to ignore common species in a conservation context. After all, if a species is abundant it should not be of much conservation interest. Instead, focus tends to be on trying to prevent the extinction of rare species. However, species that are common because they are abundant in their communities, as opposed to species considered common because they have a widespread distribution, often are keystone components of their communities. This means that if they should disappear or even just be significantly reduced in numbers, there will likely be cascading effects on other members of the community. Many local extinctions are probable, and these in turn may reduce the number of trophic levels with top carnivores being particularly vulnerable. The community may deteriorate to the point of a tipping point that will drastically change the nature of the community and prevent restoration efforts. Imagine a redwood forest (Sequoia sempervirens) suddenly deprived of its redwoods or a western North American prairie with prairiedogs (Cynomys spp.) extirpated or a European beech forest (Fagus sylvatica) without its beeches. Delibes-Mateos et al. (2011) and Gaston (2011) draw attention to this easily overlooked issue.

Climate Change Complications. Of unknown, but surely over-riding importance, is the role that climate change will make in complicating our conservation efforts. Research that enlightens how species respond in diverse ways (both genetically and non-genetically) to these threats will be most helpful in reserve planning. It might well be instructive if these responses could be predicted based on species characteristics. Intentional translocations of species across dispersal barriers may be part of the strategy. Pioneering research that documents distributional changes over the past nearly 100 years have been insightful (Moritz et al. 2008). Camacho et al. (2010) outline the challenges and suggest future research directions, while Mazziotta et al. (2014) provide a method for improving our ability to measure the response of organisms to future climate changes. Sgrò et al. (2011) discuss ways to build evolutionary resilience with climate change.

Role of Genetics. Not long ago, genetics and evolution were considered to be irrelevant for ecological investigations by most ecologists and conservationists, because of different time frames in which they were assumed to operate. Now, we know better (Allendorf et al. 2014, Frankham et al. 2009, Weeks et al. 2011). Population density bottlenecks, for example, can greatly reduce genetic variation in populations and result in deleterious inbreeding for long periods (Haig 1998). Lohr et al. (2014) have shown experimentally that one aspect of this decline in viability, namely accumulated genetic load, can lead to significant reductions in life spans. Low genetic diversity can also lead to increased susceptibility to infectious diseases (Morris et al.2012) as well as reduced potential for evolutionary 
adaptation. Fragmentation of communities can have similar effects depending on the level of connectivity among the fragments (metapopulation genetics). Loss of polymorphisms can affect social behavior, effective population size, demographic machinery on a seasonal or multiannual scale, and possibly symbiotic coactions with other species. New techniques are becoming available for using molecular markers (Haig 1998) to estimate demographic parameters such as dispersal rates and distances (vagility), invasiveness, resistance to pathogens, demic extinction rates, and aspects of social dynamics. Genetic polymorphisms may reveal insights into the spatial scale of local adaptation, temporal variations in selection pressures, mate selection, prospects for future adaptation to changing conditions, resistance to anti-regulating local extinctions (Allee effects), and the extent to which these genetic attributes vary among individuals and between neighboring demes.

Social dynamics. Mammalian social behavior varies tremendously across taxa, and can also be responsive to density, season, and local habitat conditions, and is therefore susceptible to anthropogenic changes. Understanding the dynamics of sociality in taxa and local populations of conservation interest is important as social behavior influences demographic phenomena as well as genetic composition. For these reasons, social behavior and its dynamics can be useful in understanding local extinction risks, the potential for future adaptation to change, and the likelihood that a species will be able to shift its distribution in response to climate changes. Dispersal dynamics can be strongly influenced by social behavior. Emigration, for example, can be encouraged by social cohesiveness of a group of individuals or by group aggression against excluded former members. It can also be inhibited if individuals are unwilling to leave their social environment. Laurance (1990) for example found that dispersal of a social marsupial living in large blocks of Queensland (Australia) rain forest was not possible among forest fragments even when seemingly adequate corridors were present. The chances of successful immigration into an already inhabited habitat fragment can also be strongly dependent on social interactions. As mentioned, social behavior also has numerous possible feedbacks with genetic structure.

Microorganism synergisms. The role of parasitic microorganisms as mortality agents has long held the attention of mammal ecologists. New emerging diseases are regularly being described, and with increasing globalization pathogens are being introduced around the world, often with disastrous consequences. There is also the potential for pandemics among humans based on new transfers of bacterial and viral pathogens from other species (zoonoses). Recent examples are HIV and Ebola viruses. But, what is new and exciting is the recent findings that the huge variety of micro-organisms that live on or in mammal hosts (microbiomes) can have numerous unanticipated non-pathogenic impacts on those hosts, and this includes humans (Dorit 2014). Many species are mutualistic and can influence digestion, development of immune systems, and even behavior. Moreover, the effects are not the sum of individual micro-organism/host interactions, but a product of the particular mix of symbionts present, as well as, of course, the genome of the host. Hanski et al. (2012) have discovered that humans growing up in relatively clean urban environments are much more prone to develop allergies than those experiencing rural areas with concomitant contact with a much greater diversity of microorganisms. As discussed by Dunn (2012), Hanski's research has implications also for an additional role of maintaining biodiversity, namely improving the health of mammalian inhabitants. Kohl et al. (2014) report that certain gut microbes allow woodrats (Neotoma) to feed extensively on toxic plants. Ezenwa et al. (2012) review mutual interactions between animal behavior and an individual's microbiome, and conclude that "Given the importance of chemical communication throughout the animal kingdom, symbiont alteration of host chemistry can be a potent force that shapes many fundamental animal behaviors." For example, Bravo et al. (2011) have shown experimentally that in mice (Mus musculus) the gut microbiome can influence stress, anxiety, and depression-related 
behavior through the host's neuroendocrine system. Theis et al. (2012) report that symbiotic bacteria in hyenas appear to mediate their social pheromones. Verhulst et al. (2011) have found that humans with higher microbial diversity on their skins are less attractive to the malaria mosquito (Anopheles gambiae). It is apparent that microbiome/host interactions will be found to be major influences on host behavior, health, and social interactions. Influences on mate choice may even be implicated in demic differentiation and speciation. These new insights on the diverse roles of microbiota clearly have implications for using captive breeding to save rare species, especially when reintroductions of individuals back into natural habitats are contemplated.

Translocations. As we move slowly away from the comfortable paradigm of using the past as our vision for conservation actions, we are increasingly faced with the reality that historically-based restorations and reserve management tactics are in many cases becoming irrelevant. Rampant extinctions continue in spite of our not insignificant conservation efforts (Dirzo et al. 2014), climate change that now seems very likely irreversible in human time frames, and the debut of novel communities with which we have no experience, all suggest that translocations, including reintroductions, will become increasingly important conservation tools (Seddon et al. 2014). The intentional movement of living organisms by humans to places where they currently are not present or present only in low numbers will require new skills and much new knowledge (Weeks et al. 2011).

Motivations for translocations will include: 1) saving a species from extinction, 2) helping a species cross a barrier in order to accommodate climate changes, 3) restoring genetic diversity, and hence lost vitality and improved adaptive potential to a dangerously inbred deme (Weeks et al. 2011, Whiteley et al. 2015), 4) helping a species cope with pathogens, 5) restoration of lost ecosystem services, 6) enhancing a community's defense against invasive species, 7) restoring a lost genetic polymorphism to an isolated deme, 8) helping to prevent a community suffering from cascading extinctions from descending toward a different equilibrium structure, and undoubtedly there are other reasons we do not yet know about.

If a translocation originates from captive breeding stock, we will need to worry about: a) whether the introduced individuals have a suitable microbiota for their new home, b) whether the captive breeding episode has selected against genes that might be important for successful introduction, c) whether sufficient genetic diversity will be present in the new deme for long-term future success, d) whether the social structure of the introduced cohort will be compatible to the new physical and social situation, and e) whether the new location is a novel community in which the success of our target species is untested.

\section{Conclusions}

Conservation of mammals must play a commanding role in humanity's efforts to confront the serious and complexly intertwined problems that we face. Success will depend on our abilities to work with the public and non-scientist decision makers. Five guidelines have been suggested to facilitate this required cooperation. Fundamentally important will be our success in shifting the conservation stage from a confrontational one to a situation where all of humanity recognizes that conservationists and everyone else share a single endangered planet and a common goal of sustaining human life. Simultaneously, we must pursue the scientific understanding that supports conservation. Over the past half a century, ecological research in this area has confronted a continually changing array of frontiers (Lidicker 1994, 2002). These can be roughly characterized as the progressive tackling of increasingly complex study objects. That is, there has been a shift toward focusing on successive layers of systems complexity. "Autecology" gave way to population dynamics, populations were soon seen in a community context, and then interactions between adjacent communities were acknowledged in an ecoscape context. Eight research arenas are outlined here that represent current 
challenging and exciting frontier subjects for our attention. Mammalogists have the advantage that our own species is within the taxon (Class Mammalia) with which we have special expertise. With this comes special responsibility to provide the best possible leadership that we can muster.

\section{Acknowledgements}

Thanks go to two anonymous reviewers whose comments significantly improved this manuscript.

\section{Resumen}

Introducción: Las fronteras de la biología de la conservación están avanzando rápidamente. Esto es parcialmente debido a los logros científicos, pero también se debe a que la condición humana sigue deteriorándose a pesar de los esfuerzos heroicos, pero insuficientes, para conseguir que la actividad humana sea sostenible. Es de mayor importancia la necesidad de salir del modo de confrontación que impregna nuestras discusiones sociales y políticas. Se debe de manejar este conflicto para que se comprenda que sólo hay un objetivo para toda la humanidad, y que es la sostenibilidad de la civilización humana. La conservación de mamíferos puede jugar un papel mayor en esta lucha, pero para conseguirlo, debemos tomar la iniciativa de promover un dialogo serio y activo con los políticos, economistas, sociólogos, y el público en general. Al mismo tiempo, debemos continuar con nuestros esfuerzos por alcanzar los límites de nuestra ciencia sin descuidar la búsqueda de la tan necesaria investigación básica como son la taxonomía, historia natural, y la distribución de los mamíferos del mundo.

Algunas consideraciones sociales, políticas y estratégicas: Los temas sugeridos para mejorar la comunicación son: la cooperación no conflictiva, el optimismo, los servicios de soporte de vida, sistemas de pensamiento jerárquico enfocado a los ecosistemas, y la adaptación a diferentes regímenes políticos.

Fronteras de la ciencia de la conservación: Ocho temas de vanguardia que se sugieren para el componente de la ciencia de la conservación: 1) puntos de inflexión de la comunidad, 2) las cascadas tróficas, 3) la ecología del paisaje o "ecoscapes", 4) el papel de las especies comunes en la dinámica de la comunidad, 5) complicaciones del cambio climático, 6) papel de la genética, 6) la dinámica social, 7) sinergias de microorganismos, y 8) translocaciones. Conservacionistas de mamíferos están preparados para desempeñar un papel significativo en los esfuerzos de la humanidad para enfrentar la miríada de problemas entrelazados que nos enfrentamos. Dado que los seres humanos pertenecen a la misma clase taxonómica que es objeto de nuestra experiencia, tenemos la responsabilidad especial de proporcionar ese liderazgo.

Palabras clave: cambio climático, cascadas tróficas, civilización sostenible, cooperación, comportamiento social, cría en cautiverio, genética de conservación, nueva conservación, optimismo, perspectiva del paisaje, perspectiva sistémica, puntos de inflexión de la comunidad, servicios de apoyo a la vida, sinergismos de microbiota, translocaciones.

\section{References}

Allendorf, F. W., G. Luikart, S. N. Aitken, and A. Antunes. 2013. Conservation and the genetics of populations. $2^{\text {nd }}$ ed., Wiley Blackwell. Hoboken, USA.

Bourcher, D. H. (ed.). 1985. The Biology of Mutualism. Oxford University Press. New York, USA.

Bravo, J. A., P. Forsythe, M. V. Chew, E. Escarage, H. M. Savignac, T. G. Dinan, and J. F. Cryan. 2011. Ingestion of Lactobacillus strain regulates emotional behavior and central GABA receptor expression in a mouse via the vagus nerve. Proceedings National Academy of Sciences 108:16050-16055.

Camacho, A. E., H. Doremus, J. S. Mclachlan, and B. A. Minteer. 2010. Reassessing conservation goals in a changing climate. Issues in Science and Technology 4:5.

Chapron, G., And J. V. López-Bao. 2014. Conserving carnivores: politics in play. Science 343:1199-1200.

Dal, L., V. DaAn, K. S. Korolev, And J. Gore. 2012. Generic indicators for loss of resilience before a tipping point leading to population collapse. Science 336:1175-1177.

Delibes-Mateos, M., A. T. Smith, C. N. Slobodchikoff, and J. E. Swenson. 2011. The paradox of keystone species persecuted as pests: a call for the conservation of abundant small mammals in their native range. Biological Conservation 144:335-346. 
Dirzo, R., H. S. Young, M. Galetti, G. Ceballos, N. J. B. Isaac, and Ben Collen. 2014. Defaunation in the Anthropocene. Science 345:401-406.

DoRIT, R. 2014. The superorganism revolution. American Scientist 102:330-333.

Dugatkin, L. A. 1997. Cooperation among animals, an evolutionary perspective. Oxford University Press. Oxford, United Kindom.

Dunn, R. 2012. Letting biodiversity get under our skin. Conservation 13:16-21.

Estes. J. A., J. Terborgh, J. S. Brashares, M. E. Power, J. Berger, and 19 others. 2011. Trophic downgrading of planet Earth. Science 333:301-306.

Ezenwa, V. O., N. M. Gerardo, D. W. Inouye, M. Medina, and J. B. Xavier. 2012. Animal behavior and the microbiome. Science 338:198-199.

Feinberg, M., And R. Willer. 2011. Apocalypse soon? Dire messages reduce belief in global warming by contradicting just-world beliefs. Psychological Science 22:34-38.

Frankham, R., J.D. Ballou, and D. A. Briscoe. 2009. Introduction to conservation genetics. $2^{\text {nd }}$ ed., Cambridge University Press. New York, USA.

Fung, T., R. M. Seymour, And C. R. Johnson. 2013. Warning signals of regime shifts as intrinsic properties of endogenous dynamics. American Naturalist 182:208-222.

Gaston, K. J. 2011. Common ecology. BioScience 61:354-362.

HAIG, S. M. 1998. Molecular contributions to conservation. Ecology 79:413-425.

Hanski, I., L. von Hertzen, N. Fyhrquist, and 11 others. 2012. Environmental biodiversity, human microbiota, and allergy are interrelated. Proceedings of the National Academy of Sciences 109:8334-8339.

Hughes, B. B., R. Eby, E. Van Dyke, M. T. Tinker, C. I. Marks, K. S. Johnson, and K. Wasson. 2013. Recovery of a top predator mediates negative eutrophic effects on seagrass. Proceedings of the National Academy of Sciences 110:15313-15318.

Kohl, K. D., R. B. Weiss, J. Cox, C. Dale, and M. D. Dearing. 2014. Gut microbes of mammalian herbivores facilitate intake of plant toxins. Ecology Letters: doi:10.1111/lele.112329.

Kozo-Polyansky, B. M., V. Fet, and L. Margulis. 2010. Symbiogenesis. Harvard University Press. Cambridge, USA.

LAURANCE, W. F. 1990. Comparative responses of five arboreal marsupials to tropical forest fragmentation. Journal of Mammalogy 71:641-653.

Levchenko, V. F., AND V. A. Kotolupov. 2010. Levels of organization of living systems: cooperons. Zhurnal Evoliutsionnoi Biokhimii i Fiziologii 46:530-538.

Lidicker, W. Z., JR. 1994. Population ecology. Pp. 323-347 in Seventy-five Years of Mammalogy (1919-1994) (Birney E. C., and J. R. Choate, eds.). Special Publication No. 11, American Society of Mammalogists. Lawrence, USA.

LIDICKER, W. Z., JR. 1995. The landscape concept: something old, something new. Pp. 3-19 in Landscape approaches in mammalian ecology and conservation (Lidicker, Jr. W. Z., ed.). University of Minnesota Press. Minneapolis, USA.

LIDICKER, W. Z., JR. 1999. Responses of mammals to habitat edges: an overview. Landscape Ecology 14:333-343.

LIDICKER, W. Z., JR. 2002. From dispersal to landscapes: progress in the understanding of population dynamics. Acta Theriologica 47 (Suppl. 1):23-37.

LIDICKER, W. Z., JR. 2007. Landscape ecology: whence came this creature? Ecology 88:2140-2141.

LIDICKER, W. Z., JR. 2008. Levels of organization in biology: on the nature and nomenclature of ecology's fourth level. Biological Reviews 83:71-78.

LIDICKER, W. Z., JR. 2010. The Allee effect: its history and future importance. The Open Ecology Journal 3:71-82.

LIDICKER, W. Z., JR. 2011. Hope and realism in conservation biology. BioScience 61:94.

Lidicker, W.Z., JR. AND J. A. Peterson. 1999. Responses of small mammals to habitat edges. Pp. 211-227 in Landscape ecology of small mammals (Barrett G. W., and J. D. Peles, eds.). Springer-Verlag. New York, USA.

Lohr, J. N., P. David, AND C. R. HaAG. 2014. Reduced lifespan and increased ageing driven by genetic drift in small populations. Evolution 68:2494-2508. 
Marvier, M. 2014. New conservation is true conservation. Conservation Biology 28:1-3.

Mazziotta, A., M. Triviño, O.-P. Tikkanen, J. Koukı, H. Standman, and M. Monkönen. 2014. Applying a framework for landscape planning under climate change for the conservation of biodiversity in the Finnish boreal forest. Global Change Biology, doi: 10.1111/gcb. 12677.

Moritz, C., J. L. Patton, C. J. Conroy, J. L. Parra, G. C. White, and S. R. Beissinger. 2008. Impact of a century of climate change on small-mammal communities in Yosemite National Park, USA. Science 322:261-264.

MorRIS, K., J.J. Austin, AND K. Belov. 2012. Low major histocompatibility complex diversity in theTasmanian devil predates European settlement and may explain susceptibility to disease epidemics. Biology Letters 9:1-5.

Redford, K. H., G. Amato, J. Baillie, And 17 others. 2011. What does it mean to successfully conserve a (vertebrate) species? BioScience 61:39-48.

Ripple, W. J., R. L. Beschta, J. K. Fortin, And C. T. Robbins. 2014a. Trophic cascades from wolves to grizzly bears in Yellowstone. Journal of Animal Ecology 83:223-233.

Ripple, W. J., J. A. Estes, R. L. Beschta, ANd 11 others. 2014b. Status and ecological effects of the world's largest carnivores. Science 343 (6167); doi: 10.1126/science. 1241484.

Seddon, P. J., C. J. Griffiths, P. S. Soorae, and D. P. Armstrong. 2014. Reversing defaunation: restoring species in a changing world. Science 345:406-412.

Sgrò, C. M., A. J. Lowe, And A. A. Hoffmann. 2011. Building evolutionary resilience for conserving biodiversity under climate change. Evolutionary Applications 4:326-337.

SörLIN, S. 2012. Environmental humanities: why should biologists interested in the environment take the humanities seriously? BioScience 62:788-789.

Swaisgood, R. R. AND J. K. Sheppard. 2010. The culture of conservation biologists: show me the hope! BioScience 60:626-630.

Theis, K. R., T. M. Schmidt, and K. E. Holekamp. 2012. Evidence for a bacterial mechanism for groupspecific social odors among hyenas. Scientific Reports 2 (615):1-20.

Verhulst, N. O., Y. T. Qui, H. Beijleveld, C. Maliepaad, D. Knights, S. Schulz, and 12 others. 2011. Composition of human skin microbiota affects attractiveness to malaria mosquitoes. PLOS ONE 6 (12): e28991; doi: 10. 1371/journal.pone 0028991.

Weeks, A. R., C. M. Sgro, A.G. Young, R. Frankham, N. J. Mitchell, K. A. Miller, and 7 others. 2011. Assessing the benefits and risks of translocations in changing environments: a genetic perspective. Evolutionary Applications 4:709-725.

White, J. F., M. S. Torres (eds). 2009. Defensive mutualism in microbial symbiosis. CRC Press. Boca Raton, USA.

Whiteley, A. R., S. W. Fitzpatrick, W. C. Funk, and D. A. Tallmon. 2015. Genetic rescue to the rescue. Trends in Ecology \& Evolution 30:42-49.

Wiens, J. A., M. R. Moss, M. G. Turner, And D. J. Mladenoff. 2007. Foundation Papers in Landscape Ecology. Columbia University Press. New York, USA.

Wilmers, C. C., J. A. Estes, M. Edwards, K. L. Laidre, and B. Konar. 2012. Do trophic cascades affect the storage and flux of atmospheric carbon? An analysis of sea otters and kelp forests. Frontiers in Ecology and the Environment 10:409-415.

Summited: October 8, 2014

Review: January 8, 2015

Accepted: January 28, 2015

Associated editor: Jesus Maldonado 